\title{
Variability of semen in boars treated with vitamin C in food ration
}

\author{
JERZY LECHOWSKI, ANNA KASPRZYK*, BEATA TRAWIŃSKA** \\ Department of Biochemistry and Toxicology, *Department of Breeding and Pig Production, \\ **Department of Animal Hygiene and Environment, Faculty of Biology, Animal Sciences and Bioeconomy, \\ University of Life Sciences in Lublin, Akademicka 13, 20-950 Lublin, Poland
}

Lechowski J., Kasprzyk A., Trawińska B.

Variability of semen in boars treated with vitamin $C$ in food ration

Summary

The objective of the present research was to determine the effect of different quantities of vitamin C supplied and of its subsequent withdrawal on selected physical and chemical characteristics of ejaculate collected from boars of the Duroc and Hampshire breeds, as well as Duroc $\times$ Hampshire $(\mathrm{D} \times \mathrm{H})$ and Hampshire $\times$ Duroc $(H \times D)$ crossbreds. The control group $(C)$ consisted of 4 Durocs, 4 Hampshires, 4 Duroc $\times$ Hampshire crossbreds and 4 Hampshire $\times$ Duroc crossbreds. The same animals made up the experimental groups: E1, E2, and E3. The boars in groups E1 and E2 were consecutively supplied with vitamin $\mathrm{C}$ in the spring season, as follows: $2.4 \mathrm{~g} / 100 \mathrm{~kg}$ b.w./day was administered to $\mathrm{E} 1 \mathrm{for} 30$ days, and then $1.3 \mathrm{~g} / 100 \mathrm{~kg}$ b.w./day was given to $\mathrm{E} 2$ for another 30 days. In group E3, vitamin $\mathrm{C}$ supplementation was ceased. Ejaculates were evaluated to measure the following traits: ejaculate volume, sperm concentration, sperm count in total ejaculate and in a dose of ejaculate, progressive motility, and the number of doses.

A significant positive effect of vitamin $\mathrm{C}$ administered in amounts of $2.4 \mathrm{~g}$ and $1.3 \mathrm{~g}$ on ejaculate volume was observed in Durocs and $\mathrm{D} \times \mathbf{H}$ hybrids. With respect to Hampshires and $\mathrm{D} \times \mathbf{H}$ hybrids, statistically significant differences (at $P \leq \mathbf{0 . 0 1}$ ) were observed between groups $C$ and $E 3$. The concentration of sperm cells in $1 \mathrm{ml}$ of ejaculate was higher in samples from the experimental groups compared with samples from the control group, and this relationship depended on the amount of vitamin $\mathrm{C}$ administered and on the discontinuation of administration. A significant $(\mathrm{P} \leq \mathbf{0 . 0 1})$ increase in sperm count in total ejaculate was noted in Durocs, $\mathrm{D} \times \mathrm{H}$ crossbreds and $H \times D$ crossbreds in groups E1 and E3 and in Hampshires in E1, E2 and E3. A significant improvement in the progressive motility of sperm was noted in Hampshires in groups E1, E2, and E3. Fourteen days after vitamin $\mathrm{C}$ withdrawal in group $\mathrm{E3}$, the highest $\mathrm{pH}$ value and alkaline phosphatase (ALP) activity were observed.

Keywords: boar, vitamin C, semen parameters, enzymes

The main criterion for keeping a boar at an insemination station is the production of boar ejaculates containing a high quantity of spermatozoa with a high fertilization potential. The production of boar semen is affected by the biological value of the boar $(22,44)$ and by environmental factors $(4,46)$. As far as the biological value is concerned, the breed of the boar is considered to be of paramount importance $(17,36$, $39,45)$ as it has critical influence on most semen traits. The age of the animal also plays a role $(20,32,38,44)$. Among the environmental factors, the most important are the rearing conditions coupled with an appropriate nutrition strategy. Currently, boars of sire breeds (lines) selected for commercial use as AI sires are subjected to reproductive, fattening and slaughter evaluation.
Recently, there have been reports of problems related to the deterioration of boar reproductive traits, such as reduced sexual activity and poor semen quality $(2,18,19,35)$. There could be many reasons for that, e.g. excessive physiological burden associated with the fast growth rate resulting from intensive selection based on fattening and slaughter traits. The process of spermatogenesis can be affected deleteriously by other environmental factors, such as pesticides, exogenous female hormones and heavy metals, while positive effects may come from feed supplementation with, among others, carnitine, arginine, selenium and vitamin E. Administration of vitamins B12, B6 and PP contributes to increased sperm cell counts and improves their motility (23). Importantly, the effectiveness of 
antioxidants, such as vitamins $\mathrm{C}$ and $\mathrm{E}$, glutathione and coenzyme Q10, in infertility treatment has been proven (37).

Boar sperm are highly sensitive to peroxidative damage due to the high content of unsaturated fatty acids in the phospholipids of the sperm plasma membrane (29). The sperm cells' susceptibility to oxidant damage depends on the balance between the extent of pro-oxidant stress and the antioxidant levels present. Most antioxidants have a large number of alternation double bonds which can act as electron traps. Vitamin $\mathrm{C}$ (ascorbic acid) is one of the most common antioxidants. The common property it shares with the other antioxidants is its ability to inactivate toxic oxygen free radicals. As a free-radical scavenger, vitamin $\mathrm{C}$ can react directly with superoxide and hydroxyl anions, as well as various lipid hydroxyperoxides with and without enzyme catalysts. It is a chain-breaking antioxidant, indirectly scavenging oxygen free radicals by recycling tocopherol to the reduced form (1). It is believed that vitamin $\mathrm{C}$, as an antioxidant, might prevent the production of mutagenic electrophilic metabolites, and stimulate 7-a-hydroxylation of lipids and cholesterol nuclei, thus enhancing their degradation to bile acids, which could be excreted from the body (28).

The appropriate amount of vitamin $\mathrm{C}$ supplied to the organism ensures the proper functioning of the nervous system, as this vitamin is used by the adrenals in the production of all adrenal hormones (most notably cortisol) that counteract stress. Intense stressful situations cause the precipitation of vitamin $\mathrm{C}$, promote its excretion in body fluids and thus increase demand for this vitamin. In light of the above, a dietary supplementation of vitamin $\mathrm{C}$ with well-known antioxidant activity plays a key role in the inhibition of oxidative stress (11), which disturbs proper functions of sperm cells and constitutes one of the causes of male infertility (16). Więckowski (43) recommends 2.0-2.5 g vitamin $\mathrm{C}$ daily per adult pig.

Of all species of farm animals, pigs synthesize the smallest amount of vitamin C (25). In view of intensive production, stress and the widespread lack of vitamin $\mathrm{C}$ in the feed industry, it is advisable to add vitamin $\mathrm{C}$ to pig feed (43). According Chinoy at al. (7), ascorbic acid deficiency caused deterioration in the reproductive performance of guinea pigs. Sönmez et al. (40) suggest that ascorbic acid supplementation improves reproductive traits of male rats, which is associated with high fertility. In the available literature, there is little data on the effect of vitamin $\mathrm{C}$ on these processes in boars.

The objective of the present study was to determine the effect of the administration of vitamin $C$, followed by its withdrawal, on selected physical and chemical characteristics of ejaculate collected from boars of the Duroc and Hampshire breeds as well as from Duroc $\times$ Hampshire crossbreds and Hampshire $\times$ Duroc crossbreds.

\section{Material and methods}

The study was conducted on a group of 2-year-old boars kept at an artificial insemination station. They were kept under the same housing (temperature and humidity), feeding and breeding conditions. The animals were fed a commercial full-ration diet in compliance with the norms, according to the Polish Swine Nutrition Requirements (33). It was a diet completely free of vitamin C, as assayed according to the Roe and Kuether laboratory method modified by Dabrowski and Hinterleitner (9). The animals were individually fed a commercial complete feed mixture for breeding boars. According to a laboratory analysis, the basic nutritional values of the complete feed mixture were as follows: 12 metabolisable energy (MJ), $177 \mathrm{~g}$ crude protein, $65.2 \mathrm{~g}$ crude fibre, $8.8 \mathrm{~g}$ calcium, and $7.7 \mathrm{~g}$ phosphorus per $\mathrm{kg}$ of the mixture. The composition of the premix per $\mathrm{kg}$ of the diet was the following: vitamin A - $150000 \mathrm{IU}$, vitamin D3 - $20000 \mathrm{IU}$, vitamin E - $120 \mathrm{mg}$, vitamin $\mathrm{K}-2.25 \mathrm{mg}$, vitamin $\mathrm{B} 1-2.25 \mathrm{mg}$, vitamin $\mathrm{B} 2-6 \mathrm{mg}$, vitamin B6 - $4.5 \mathrm{mg}$, vitamin B12 - $37.50 \mathrm{mcg}$, biotin $480 \mathrm{mcg}$, niacin $-30 \mathrm{mg}$, pantothenic acid $-15 \mathrm{mg}$, folic acid $-4.5 \mathrm{mg}$, choline chloride $-420 \mathrm{mg}, \mathrm{Fe}-144 \mathrm{mg}$, $\mathrm{Mn}-76.8 \mathrm{mg}, \mathrm{Zn}-144 \mathrm{mg}, \mathrm{Cu}-25.73 \mathrm{mg}, \mathrm{I}-1.92 \mathrm{mg}$, $\mathrm{Se}-0.48 \mathrm{mg}$. The control group (C) consisted of Durocs $(\mathrm{n}=4)$, Hampshires $(\mathrm{n}=4)$, Duroc $\times$ Hampshire crossbreds $(\mathrm{n}=4)$, and Hampshire $\times$ Duroc crossbreds $(\mathrm{n}=4)$, from which ejaculates were collected every fourth day. The same group of animals made up the experimental groups: E1, E2, and E3. During the spring months, the boars in groups $\mathrm{E} 1$ and E2 were consecutively given vitamin $\mathrm{C}$ in tapering doses: $2.4 \mathrm{~g} / 100 \mathrm{~kg}$ b.w./day was administered to E1 for 30 days, and then $1.3 \mathrm{~g} / 100 \mathrm{~kg}$ b.w./day was supplied to E2 for another 30 days. Vitamin $\mathrm{C}$ supplementation in group E3 was ceased. Group E3 was formed of the same animals in order to determine why further increase in the ascorbic acid level in boar blood plasma after the cessation of exogenous vitamin $\mathrm{C}$ supply had an effect on semen quantity and quality. To ensure the administration of a vitamin $\mathrm{C}$ dose required in the study, the animals were housed in individual pens and received vitamin $C$ in a small feedstuff portion placed in the empty trough before the full-feed ration was given. During the period of boars' saturation with vitamin $\mathrm{C}$, in group E1, ejaculates were collected every fourth day, starting on the 14 day of vitamin administration, which, according to Więckowski (43), is the time of full saturation with vitamin C. In group E2, ejaculates were also collected every fourth day after 14 days of vitamin administration. Fourteen days after the cessation of vitamin C supply, ejaculates were recollected from E2 boars and group E3 was formed of these boars. A total of 256 ejaculates were collected from all boars (from 4 animals of each breed group under study) during the spring months. The experimental design is presented in Tab. 1.

The semen was collected by the gloved-hand technique into a plastic collector (bag) with the possibility to separate the gelatinous fraction from the liquid part of the ejaculate. Immediately after collection, the volume of semen was measured with a scalar cylinder. The concentration of sperm was evaluated with a Sperma Cue device (Model $12300 / 0500$, Minitube International, Verona, USA). On the 
Tab. 1. Experiment scheme and the number of ejaculates collected

\begin{tabular}{|l|r|r|r|r|r|}
\hline \multirow{2}{*}{ Parameters studied } & \multicolumn{4}{|c|}{ Groups/Samples } & \multirow{2}{*}{ Total } \\
& C & E1 & E2 & E3 & \\
\hline Duroc (D) & 16 & 16 & 16 & 16 & 64 \\
\hline Hampshire (H) & 16 & 16 & 16 & 16 & 64 \\
\hline Duroc $\times$ Hampshire (D × H) & 16 & 16 & 16 & 16 & 64 \\
\hline Hampshire × Duroc (H × D) & 16 & 16 & 16 & 16 & 64 \\
\hline Total number of ejaculates & 64 & 64 & 64 & 64 & 256 \\
\hline
\end{tabular}

basis of semen volume and sperm concentration, the total number of sperm in the ejaculate was calculated. The vitality of the sperm was measured by a simple method developed for commercial piggery laboratories, based on the observation of motile spermatozoa under the microscope without the addition of chemical reagents. In native semen, the percentage of motile spermatozoa was determined microscopically. The proportion of correctly motile spermatozoa in the total number of visible spermatozoa was determined (5). Then, the percentage of motile spermatozoa and the total number of spermatozoa were multiplied to obtain the total number of motile spermatozoa. Immediately after the assessment, semen was diluted with a short-term BTS boar semen extender (Ver. 13525/0100 Antibiotic free, Minitube International, Verona, USA).

The ejaculates were evaluated to determine the following physical traits: ejaculate volume, concentration of spermatozoa counted microscopically by means of cell-counting chambers, percentage of progressively motile spermatozoa, total ejaculate sperm count, and the number of insemination doses per ejaculate. The ejaculate volume was determined on the basis of ejaculate weight measured with electronic scales. The sperm concentration in the ejaculates was determined by a photometric method with a SmartSpec ${ }^{\mathrm{TM}} 3000$ (Bio-Rad) spectrophotometer. The percentage of adequately motile spermatozoa was determined microscopically. The percentage share of correctly motile spermatozoa in the total number of spermatozoa visible within the scope was determined at approximately $200 \times$ fold magnification. The total number of spermatozoa with correct motility and the number of insemination doses obtained from one ejaculate were calculated using the SYSTEM SUL v. 6.35 computer program. Shortly afterwards, the ejaculates were also examined for $\mathrm{pH}$ and alkaline phospahatase (ALP) activity using a Cormay Plus device with ready-to-use Cormay test kits.

The results were analyzed statistically by analysis of variance (Statystyka 5.0) according to the following model:

$$
\mathrm{Y}=\mu+\mathrm{a}_{\mathrm{i}}+\mathrm{b}_{\mathrm{j}}+\mathrm{e}_{\mathrm{ij} \mathrm{j}} \text {, }
$$

where: Yij - value of the characteristic examined, $\mu$-population mean, $\mathrm{a}_{\mathrm{i}}$ - the effect of vitamin $\mathrm{C}, \mathrm{b}_{\mathrm{j}}$ - boar breed effect, $\mathrm{e}_{\mathrm{ijk}}$ - error. The significance of inter-group differences was verified by Duncan's test at $\mathrm{P} \leq 0.05$ and $\mathrm{P} \leq 0.01$.

\section{Results and discussion}

The research studies indicate that the vitamin C dose significantly differentiated the volume of boar ejaculate (Tab. 2, 3). The volume of ejaculate from Durocs and Duroc $\times$ Hampshire crosses in groups E1, E2 and E3 was significantly (at $\mathrm{P} \leq 0.01$ ) higher than that from the control animals (group C). In the case of Hampshires and Hampshire $\times$ Duroc crosses, statistically significant differences (at $\mathrm{P} \leq 0.01$ ) were noted between groups $\mathrm{C}$ and E3. The highest increase (by $69.15 \mathrm{ml}$ ) in ejaculate volume was determined in Hampshire $\times$ Duroc crossbreds in group E3 (Tab. 3). The highest level of sperm cell concentration in $1 \mathrm{ml}$ of ejaculate (154.35 million/ ml) was noted for Duroc $\times$ Hampshire crossbreds in group E3 (Tab. 3). A significant $(\mathrm{P} \leq 0.01)$ increase in sperm count was noted for Durocs, Duroc $\times$ Hampshire crosses and Hampshire $\times$ Duroc crosses in groups E1 and E3 and for Hampshires in groups E1, E2, and E3 (Tab. 2, 3). The greatest increase (by 24.78 billion) in the number of spermatozoa in total ejaculate was found in Hampshires in E3. Changes in sperm count in a single insemination dose were the largest (max. increase of 1.49 billion) for Durocs in group E1, and they were statistically significant $(\mathrm{P} \leq 0.01)$. Vitamin $\mathrm{C}$ supplementation improved the percentage of spermatozoa with progressive motility in most experimental groups. Only in the case of Durocs, the percentage of sperm cells with progressive motility was smaller in group E2 than it was in C, but the difference was not statistically significant. The highest increase in this parameter (by $17.50 \%$ ), compared with its value in group $\mathrm{C}$, was determined in Hampshire boars in E3. A significant $(\mathrm{P} \leq 0.01)$ differentiation in the number of semen doses was noted in Hampshires in groups E1, E2, and E3, in Durocs in E1 and E3, and in both Duroc $\times$ Hampshire and Hampshire $\times$ Duroc crossbreds in E3. The greatest statistically significant improvement in this respect was noted in Durocs in E1 (increase by 8 doses), followed by Duroc $\times$ Hampshire crossbreds in E3 (increase by 5.52 doses). Additionally, an increase in the ejaculate $\mathrm{pH}$ value was observed in boars supplied with vitamin $\mathrm{C}$ at a dose of $2.4 \mathrm{~g} / 100$ $\mathrm{kg}$ b.w./day (E1) as well as in group E3 (Tab. 4). The most pronounced $\mathrm{pH}$ value increase (by 0.39 unit) was found in the ejaculate of Hampshire $\times$ Duroc crossbreds in E1. Regarding alkaline phosphatase activity in all experimental groups, as compared with control, this parameter showed an upward trend. Its increase ranged from $3070 \mathrm{U} / 1$ in Hampshire boars in E2 up to $18010 \mathrm{U} / 1$ in Durocs in E1.

AI plays an important role in animal breeding by increasing the use of genetically superior sires (27, $39)$. Basic semen traits that affect the profitability of an AI center are volume, sperm concentration, and gross sperm morphology (30). Sperm cell concentration in $1 \mathrm{ml}$ of ejaculate varied subject to the vitamin $\mathrm{C}$ amount supplied to the animals and the intensity of the process of vitamin $\mathrm{C}$ autosynthesis in the body (Tab. 2, 3). Increasing the number of viable sperm cells has important practical consequences for artificial insemination (3). The number of insemination doses is of primary economic importance, since the higher number of usable insemination doses means lower 
costs of boar management. The number of semen doses obtained from a single ejaculate depends, according to Banaszewska and Kondracki (3), on ejaculate volume, sperm cell concentration, and motility. With enzyme contribution, sperm cells break down fructose, glucose and mannose to lactic acid. Studies by KrasińskaCzerlunczakiewicz (24), Heugten (13) and Pion et al. (31) proved that vitamin C plays a key role in enhancing lactic acid metabolism, and thus it is conducive to the reduction of its level in blood. The analysis of the results presented in this study indicates that a similar vitamin $\mathrm{C}$-induced process may have been responsible for the increase in the $\mathrm{pH}$ value monitored in boar semen.

The results on ALP activity obtained in the present study in the experimental groups were consistent with data presented by Turner and McDonnell (42) and Głogowski et al. (10). A high level of ALP activity determined here favored an elevated percentage
Tab. 2. Effects of vitamin $\mathrm{C}$ administered to purebred boars on selected ejaculate traits

\begin{tabular}{|c|c|c|c|c|}
\hline \multirow{2}{*}{ Parameters studied } & \multicolumn{4}{|c|}{ Group } \\
\hline & C & E1 & E2 & E3 \\
\hline & \multicolumn{4}{|c|}{ Duroc } \\
\hline Volume of ejaculate $\left(\mathrm{cm}^{3}\right)$ & $153.70 \pm 5.30^{c}$ & $178.63 \pm 22.35^{\text {ва }}$ & $164.00 \pm 7.30^{\mathrm{Bb}}$ & $202.50 \pm 19.68^{A}$ \\
\hline Concentration of sperm cells $\left(\times 10^{6} / \mathrm{cm}^{3}\right)$ & $346.85 \pm 8.30^{c}$ & $407.60 \pm 15.60^{B}$ & $350.00 \pm 8.45^{C}$ & $460.50 \pm 35.00^{A}$ \\
\hline Sperm count in total ejaculate $\left(\times 10^{9}\right)$ & $43.20 \pm 11.20^{B}$ & $61.57 \pm 5.34^{A}$ & $44.82 \pm 10.50^{B}$ & $59.75 \pm 5.50^{A}$ \\
\hline Sperm count in a dose of ejaculate $\left(\times 10^{9}\right)$ & $3.03 \pm 0.10^{B}$ & $4.52 \pm 1.11^{\text {Аa }}$ & $3.10 \pm 0.12^{B}$ & $3.23 \pm 1.12^{\mathrm{b}}$ \\
\hline Progressive motility (\%) & $83.00 \pm 5.90$ & $85.24 \pm 4.93^{\mathrm{a}}$ & $81.42 \pm 5.20^{\mathrm{b}}$ & $84.40 \pm 6.14$ \\
\hline \multirow[t]{2}{*}{ Number of doses (unit) } & $14.00 \pm 1.62^{\mathrm{B}}$ & $22.00 \pm 2.68^{\text {Aa }}$ & $14.86 \pm 1.45^{\mathrm{B}}$ & $18.66 \pm 5.83^{\text {Ab }}$ \\
\hline & \multicolumn{4}{|c|}{ Hampshire } \\
\hline Volume of ejaculate $\left(\mathrm{cm}^{3}\right)$ & $177.50 \pm 7.56^{\mathrm{B}}$ & $179.00 \pm 7.80^{\mathrm{B}}$ & $178.70 \pm 25.17^{\mathrm{B}}$ & $206.30 \pm 20.08^{A}$ \\
\hline Concentration of sperm cells $\left(\times 10^{6} / \mathrm{cm}^{3}\right)$ & $360.30 \pm 12.35^{\circ}$ & $441.20 \pm 16.24^{A}$ & $438.80 \pm 30.46^{C}$ & $485.70 \pm 33.13^{8}$ \\
\hline Sperm count in total ejaculate $\left(\times 10^{9}\right)$ & $54.40 \pm 9.32^{C}$ & $68.00 \pm 9.45^{B}$ & $68.05 \pm 7.34^{\mathrm{B}}$ & $79.18 \pm 4.30^{A}$ \\
\hline Sperm count in a dose of ejaculate $\left(\times 10^{9}\right)$ & $3.08 \pm 0.10^{B}$ & $3.12 \pm 0.0 g^{b}$ & $3.10 \pm 1.12^{b}$ & $3.86 \pm 1.13^{\text {Аа }}$ \\
\hline Progressive motility (\%) & $70.00 \pm 6.90^{\mathrm{B}}$ & $86.70 \pm 5.20^{A}$ & $85.00 \pm 8.30^{A}$ & $87.50 \pm 8.60^{A}$ \\
\hline Number of doses (unit) & $18.00 \pm 1.48^{c}$ & $21.70 \pm 1.36^{A}$ & $19.66 \pm 1.90^{B}$ & $22.00 \pm 2.45^{A}$ \\
\hline
\end{tabular}

Explanations: A, B - means denoted with capital letters in line differ significantly at $\mathrm{P} \leq 0.01 ; \mathrm{a}, \mathrm{b}-$ means denoted with small letters in line differ significantly at $\mathrm{P} \leq 0.05$; $\mathrm{C}-$ control; E1, E2, E3 - experimental groups

Tab. 3. Effects of vitamin $\mathrm{C}$ administered to crossbred boars on selected ejaculate traits

\begin{tabular}{|c|c|c|c|c|}
\hline \multirow{2}{*}{ Parameters studied } & \multicolumn{4}{|c|}{ Group } \\
\hline & C & E1 & E2 & E3 \\
\hline & \multicolumn{4}{|c|}{ Duroc $\times$ Hampshire } \\
\hline Volume of ejaculate $\left(\mathrm{cm}^{3}\right)$ & $165.28 \pm 8.35^{c}$ & $191.50 \pm 20.30^{A}$ & $180.70 \pm 15.20^{B}$ & $220.00 \pm 25.50^{A}$ \\
\hline Concentration of sperm cells $\left(\times 10^{6} / \mathrm{cm}^{3}\right)$ & $414.50 \pm 16.00^{c b}$ & $517.75 \pm 29.90^{B}$ & $436.66 \pm 12.50^{\mathrm{ca}}$ & $568.85 \pm 28.20^{A}$ \\
\hline Sperm count in total ejaculate $\left(\times 10^{9}\right)$ & $73.44 \pm 6.90^{c}$ & $80.72 \pm 5.20^{B}$ & $73.96 \pm 7.56^{C}$ & $86.40 \pm 5.35^{A}$ \\
\hline Sperm count in a dose of ejaculate $\left(\times 10^{9}\right)$ & $3.09 \pm 0.12^{c}$ & $3.50 \pm 1.12^{b}$ & $3.45 \pm 0.09^{B}$ & $4.55 \pm 1.08^{\text {Aa }}$ \\
\hline Progressive motility (\%) & $86.06 \pm 6.70^{b}$ & $91.10 \pm 4.94^{\mathrm{a}}$ & $88.35 \pm 5.47$ & $90.00 \pm 6.30$ \\
\hline \multirow[t]{2}{*}{ Number of doses (unit) } & $20.75 \pm 1.55^{B}$ & $21.14 \pm 2.15^{\mathrm{B}}$ & $21.00 \pm 1.60^{B}$ & $26.00 \pm 3.95^{A}$ \\
\hline & \multicolumn{4}{|c|}{ Hampshire $\times$ Duroc } \\
\hline Volume of ejaculate $\left(\mathrm{cm}^{3}\right)$ & $215.85 \pm 23.30^{B}$ & $262.80 \pm 15.45^{b}$ & $227.24 \pm 24.80^{B}$ & $285.00 \pm 30.14^{\text {Aa }}$ \\
\hline Concentration of sperm cells $\left(\times 10^{6} / \mathrm{cm}^{3}\right)$ & $290.83 \pm 17.15^{c}$ & $306.04 \pm 9.69^{B}$ & $302.76 \pm 33.24^{B}$ & $341.40 \pm 33.24^{A}$ \\
\hline Sperm count in total ejaculate $\left(\times 10^{9}\right)$ & $52.97 \pm 6.34^{C}$ & $64.28 \pm 7.20^{B}$ & $55.16 \pm 6.20^{c}$ & $71.12 \pm 6.32^{A}$ \\
\hline Sperm count in a dose of ejaculate $\left(\times 10^{9}\right)$ & $3.10 \pm 0.10^{b}$ & $3.16 \pm 0.08^{b}$ & $3.12 \pm 1.11^{b}$ & $3.68 \pm 1.00^{\mathrm{a}}$ \\
\hline Progressive motility (\%) & $78.00 \pm 6.70^{\mathrm{b}}$ & $81.43 \pm 7.00$ & $80.00 \pm 7.25$ & $83.85 \pm 8.40^{\mathrm{a}}$ \\
\hline Number of doses (unit) & $17.14 \pm 1.51^{b}$ & $18.40 \pm 1.72^{\mathrm{Ba}}$ & $17.23 \pm 1.90^{B}$ & $20.66 \pm 2.62^{A}$ \\
\hline
\end{tabular}

Explanations: as in Tab. 2

Tab. 4. Effects of vitamin $\mathrm{C}$ administered to boars on $\mathrm{pH}$ and alkaline phosphatase activity in ejaculate

\begin{tabular}{|l|c|c|c|c|c|c|c|c|}
\hline \multirow{2}{*}{ Breeds and crossbreds } & \multicolumn{4}{|c|}{ pH } & \multicolumn{4}{|c|}{ Activity of alkaline phosphatase U/I } \\
& C & E1 & E2 & E3 & C & E1 & E2 & E3 \\
\hline Duroc & $7.25 \pm 0.11^{\mathrm{B}}$ & $7.53 \pm 0.24^{\mathrm{A}}$ & $7.37 \pm 0.22$ & $7.47 \pm 0.23^{\mathrm{A}}$ & $35120 \pm 2685^{\mathrm{C}}$ & $53130 \pm 3263^{\mathrm{A}}$ & $42200 \pm 2892^{\mathrm{B}}$ & $52140 \pm 3240^{\mathrm{A}}$ \\
Hampshire & $7.28 \pm 0.12^{\mathrm{Bb}}$ & $7.53 \pm 0.22^{\mathrm{Aa}}$ & $7.34 \pm 0.19^{\mathrm{b}}$ & $7.44 \pm 0.22^{\mathrm{a}}$ & $40440 \pm 2854^{\mathrm{C}}$ & $51470 \pm 3365^{\mathrm{A}}$ & $43510 \pm 3042^{\mathrm{B}}$ & $53670 \pm 3300^{\mathrm{A}}$ \\
\hline Duroc $\times$ Hampshire & $7.25 \pm 0.15^{\mathrm{Bb}}$ & $7.55 \pm 0.25^{\mathrm{A}}$ & $7.28 \pm 0.24^{\mathrm{B}}$ & $7.44 \pm 0.24^{\mathrm{a}}$ & $36810 \pm 2965^{\mathrm{C}}$ & $49330 \pm 3523^{\mathrm{A}}$ & $44890 \pm 3386^{\mathrm{B}}$ & $50330 \pm 3520^{\mathrm{A}}$ \\
\hline Hampshire $\times$ Duroc & $7.18 \pm 0.13^{\mathrm{B}}$ & $7.57 \pm 0.26^{\mathrm{A}}$ & $7.41 \pm 0.26^{\mathrm{B}}$ & $7.54 \pm 0.25^{\mathrm{A}}$ & $35780 \pm 3487^{\mathrm{B}}$ & $48260 \pm 3475^{\mathrm{Ab}}$ & $45850 \pm 3501^{\mathrm{Ab}}$ & $49000 \pm 3450^{\mathrm{Aa}}$ \\
\hline
\end{tabular}

Explanations: as in Tab. 2 
of spermatozoa with progressive motility, providing sperm cells with greater amount of energy generated, according to Stryer et al. (41), in the process of glucose conversion into fructose in male semen under the influence of ALP. Stryer et al. point out that the activation of enzyme reactions in the accessory gland tissues triggers the conversion of glucose into fructose. A key role in this process is attributed to alkaline phosphatase found in seminal vesicle secretion which, as was demonstrated (41), breaks down phosphohexoses to phosphoric acid and free fructose. The breakdown of fructose, that is, fructolysis, is considered the most vital process providing the energy indispensable for sperm cell motility. It should be noted that only mammals are able to use fructose as the major source of energy in this process (41). Therefore, alkaline phosphatase present in ejaculate proves to be one of the main enzymes providing energy to spermatozoa. The activity of ALP changes subject to, among others, the duration of daylight, which was highlighted by Kozdrowski and Dubiel (22). The present study shows that vitamin C may be another agent that elevates ALP activity, and, as the research findings demonstrate, a dose of this vitamin elicits different levels of ALP activity (Tab. 4). Likewise, the withdrawal of vitamin $C$ from the boars ' diet in group E3 contributed to the growing activity of ALP, most probably by stimulating the autosynthesis of this vitamin, as observed by Więckowski (43) and Lechowski (26). Studies conducted by Lechowski (26) showed that on day 14 after cessation of vitamin C supplementation, there was an elevated activity of L-gulono-gamma-lactone oxidase enzyme involved in the final stage of L-gulono-gamma-lactone conversion into ascorbic acid in its biosynthesis. Importantly, the increase in the activity of this enzyme is concurrent with the decrease in vitamin $\mathrm{C}$ content in tissues and organs, which, as Lechowski (26) reports, results from the absence of vitamin $\mathrm{C}$ supply from an exogenous source. In addition, this author highlights a feedback mechanism between enzyme activity and product concentration, i.e. an excessive accumulation of the synthesis product inhibits enzyme activity in this process. Hence, high dietary doses of vitamin $\mathrm{C}$ have a stimulating effect: in the first stage, enzyme activity is inhibited, whereas in the following stage, after vitamin $\mathrm{C}$ has been withdrawn and its level in the body has decreased, the activity of L-gulono-gammalactone oxidase enzyme is increased. As Lechowski (26) suggests, the mechanism outlined above is likely to become activated in order to compensate for the difference between the higher level of vitamin C solidified in the body after long-term administration and its decrease after supplementation has stopped.

Lin et al. (27) and Close and Cole (8) found that a vitamin $\mathrm{C}$ dietary additive improved to some extent the quality of boar semen in periods of repeated high ambient temperatures. Similarly, Ivos et al. (14) associate an increased gilt conception rate in summer with increased vitamin $\mathrm{C}$ supplementation. According to Yousef et al. (47), a combination of ascorbic acid and vitamin E effectively reduces the production of free radicals and thus improves semen quality. Greer et al. (12), in studies conducted at 5 different farms where vitamin $\mathrm{C}$ ( $4 \mathrm{~g}$, unit/day) was supplied to a half of gilts and boars in the summer season, did not note any marked improvement in gilt performance. Jacyno et al. (15) pointed out that vitamin $\mathrm{C}$ affects L-carnitine synthesis, which in turn has positive effect on all semen traits analyzed. The analysis of the present research results indicates that vitamin $\mathrm{C}$ has direct and indirect influence on these parameters.

Vitamin C supplied to boars in the experimental groups, significantly differentiated most semen parameters, increasing their values, compared with those in the control group, with the highest increase recorded in group E1. The reduction of the vitamin C dose decreased the value of each ejaculate parameter in group E2 compared with group E1. The cessation of vitamin $\mathrm{C}$ administration to group E3 caused an increase in all semen quality parameters for boars in this group. The higher activity of alkaline phosphatase in seminal vesicle secretion, which was observed in the experimental groups, provided more energy for spermatozoa and contributed to the rising percentage of progressively motile sperm cells. The inclusion of vitamin $\mathrm{C}$ in the feed rations of boars in all experimental groups affected the increase in semen $\mathrm{pH}$ values. The results of the present study show the importance of the dietary supply of vitamin $\mathrm{C}$ for a significant boost in boar fertility.

\section{References}

1. Atanacio S. A. C., Atanga P. A., Atazan J. C. M., Atienza B. J. B., Atutubo C. E. C., Austria A. A. G., Avanceña F. M. C., Balan R. A. T., Balaoing G. D. A., Bambico D. J. M., Banzon C. M. G., Barcarse F. A., Barcenas R. M. R., Barrera D. J. A., Barsaga C. N. P., Bascos B. B., Basilio F. A. D., Batac J. A. L., Bataller N. J. D., Bautista A. E.: The effect of vitamin C supplementation on the sperm count of male albino rats subjected to immobilization stress. Subsection A3 Batch 2010, 1-38.

2. Banaszewska D., Kondracki S.: An assessment of the breedingmaturity of insemination boars based on ejaculate quality changes. Folia Biol. Kraków 2012, 60, 151-162.

3. Banaszewska D., Kondracki S.: Sexual development of boars insemination. Przegl. Hod. 2005, 10, 8-10 (in Polish).

4. Banaszewska D., Kondracki S., Wysokinska A.: The influence of the season on the sperm morphology young boars used for insemination. Acta Sci. Pol. Zoot. 2007, 6, 3-14.

5. Bennett G. H., O'Hagan C.: Factors influencing the success of artificial insemination in pigs. Proc. $V^{\text {th }}$ Int. Congr. Anim. Reprod. Artif. Insem., 6-13 September, Trento, Italy1964, 4, 481-487

6. Čerovsky J., Frydrychova S., Lustykova A., Lipensky J., Rozkot M.: Semen characteristics of boars receiving control diet and control diet supplemented with L-carnitine. Czech J. Anim. Sci. 2009, 54, 417-425.

7. Chinoy N. J., Mehta R. R., Seethalakshmi L., Sharma J. D., Chinoy M. R.: Effects of vitamin $C$ deficiency on physiology of male reproductive organs of guinea pigs. Int. J. Fertil. 1986, 31, 232-239.

8. Close W. H., Cole D. J. A.: Don't ignore the boar! Minerals and vitamins for breeding boars. Feed Mix. 2001, 9, 8-11.

9. Dabrowski K., Hinterleitner S.: Application of a simultaneous assay of ascorbic acid, dehydroascorbic acid and ascorbic sulphate in biological materials. Analyst 1989, 114, 83-87.

10. Głogowski J., Danforth D. R., Ciereszko A.: Inhibition of alkaline phosphatase activity of boar semen by pentoxifylline, caffeine, and theophylline. J. Androl. 2002, 23, 1-15 
11. Golden C., Rosenkrans C., Johnson Z.: Effects of ascorbic acid and alphatocopherol on cryopreserved boar sperm. Arkansas Anim. Sci. Depart. Rep. 2002, 499, 120-123.

12. Greer E. B., Gardner I. A., Wright G. L.: Failure of dietary vitamin C supplementation to prevent seasonal infertility in pigs. Aust. J. Exp. Agr. 1987, 27, 343-347.

13. Heugten E.: Can vitamin C improve pork quality? Swine News 2004, 27, 34-38.

14. Ivos J., Doplihar C., Muhaxhiri G.: Thermic stress as a factor of disturbances in the reproduction of pigs and possibility of prevention of these disturbances by the addition of ascorbic acid. Vet. Archiv 1971, 41, 202-216.

15. Jacyno E., Kołodziej A., Kamyczek M., Kawęcka M., Dziadek K., Pietruszka A.: Effect of L-carnitine supplementation on boar semen quality. Acta Vet. Brno 2007, 76, 595-600

16. Jedlińska-Krakowska M.: Oxidative stress and the influence of reactive oxygen species on the function of semen. Med. Weter. 2005, 61, 1122-1123 (in Polish).

17. Kawęcka M., Pietruszka A., Jacyno E., Czarnecki R., Kamyczek M.: Quality of semen of young boars of the breeds Pietrain and Duroc and their reciprocal crosses. Arch. Tierz. 2008, 51, 42-54.

18. Knecht D., Jankowska-Mąkosa A., Duziński K.: The dependence of the growth rate and meat content of young boars on semen parameters and conception rate. Anim. 2017, 11, 802-810.

19. Kołodziej-Skalska A.: Wpływ stosowania L-karnityny oraz chromu organicznego w żywieniu młodych knurów linii 990 na ich ocenę przyżyciową przydatność do rozpłodu oraz wybrane wskaźniki biochemiczne surowicy i osocza nasienia Praca hab. Zachodniopomorski Uniwersytet Technologiczny w Szczecinie 2013.

20. Kondracki S., Banaszewska D., Mielnicka C.: The effect of age on morphometric sperm traits of domestic pigs (Sus scrofa domestica). Cell. Mol. Biol. Lett. 2005, 10, 3-13.

21. Kondracki S., Wysokińska A., Iwanina M., Banaszewska D., Sitarz D.: Effect of sperm concentration in an ejaculate on morphometric traits of spermatozoa in Duroc boars. Polish J. Vet. Sci. 2011, 14, 35-40.

22. Kozdrowski R., Dubiel A.: The effect of season on the properties of wild boar (Sus scrofa L.) semen. Anim. Reprod. Sci. 2004, 80, 281-289.

23. Kozink D. M., Estienne M. J., Harper A. F., Knight J. W.: Effect of dietary L-carnitine supplementation on semen characteristics in boars. Theriogenol. 2004, 61, 1247-1258.

24. Krasińska-Czerlunczakiewicz $H$.: Effect of intravenous administration of ascorbic acid on the concentrations of glucose, fructose, lactic acid and pyruvic acid in the blood of patients with acute ischemic brain disorders in the early stage of the disease (in Polish). PhD Diss, Akademia Medyczna, Lublin 1995.

25. Kubiński T.: Witamina C u zwierząt. Nowa Wet. 1993, 2, 38-43.

26. Lechowski J.: Evaluation the effect of dietary ascorbic acid supplementation on the performance parameters of young gilts and insemination boars as well as physical and chemical properties of fatteners' meat. Rozpr. Nauk. 334. Uniwersytet Przyrodniczy w Lublinie 2009 (in Polish)

27. Lin H. K., Chen S. Y., Huang C. Y., Kuo Y. H., Wung L. C.: Studies on improving semen quality of working boars fed diets with addition of vitamin $C$ in summer season. Ann. Res. Rep. Animal Industry Research Institute, Taiwan Sugar Corporation 1985, 73/74, 59-73

28. Mishra M., Acharya U. R.: Protective action of vitamins on the spermatogenesis in lead-treated Swiss mice. J. Trace. Elem. Med. Bio. 2004, 18, 173-178.

29. Mongkol T., Buranaamnuay K., Tantasuparuk W., Am-In N.: Improvement of semen quality by feed supplement and semen cryopreservation in swine, [in:] Alemayehu L. (ed.): Success in Artificial Insemination - Quality of Semen and Diagnostics Employed. Publisher: In TechOpen, Chapters 2013, p. 17-37 DOI: $10.5772 / 51737$.

30. Oh S. H., See M. T., Long T. E., Galvin J. M.: Genetic parameters for various random regression models to describe total sperm cells per ejaculate over the reproductive lifetime of boars. J. Anim. Sci. 2006, 84, 538-545.

31. Pion S. J., van Heugten E., See M. T., Larick D. K., Pardue S.: Effect of vitamin $\mathrm{C}$ supplementation of plasma ascorbic acid and oxalate concentrations and meat quality in swine. J. Anim. Sci. 2004, 82, 2004-2012.

32. Pokrywka K., Tereszkiewicz K., Molenda P.: The impact of season of birth and age of boars of Polish Landrace breed on breeding operation results. Acta Sci. Pol. Zoot. 2016, 15, 53-64

33. Polish Swine Nutrition Requirements: IFiŻZ, PAN, Omnitech Press, Warszawa 1993 (in Polish)

34. Robinson J. A. B., Buhr M. M.: Impact of genetic selection on management of boar replacement. Theriogenol. 2005, 63, 668-678.

35. Savić R., Petrović M.: Variability in ejaculation rate and libido of boars during reproductive exploitation. S. Afr. J. Anim. Sci. 2015, 45, 355-361.
36. Savić R., Petrović M., Radojković D., Radović Č., Parunović N.: The effect of breed, boar and season on some properties of sperm. Biotechnol. Anim. Husban. 2013, 29, 299-310.

37. Sinclair S.: Male infertility: nutritional and environmental considerations Alternative Med. Rev. 2000, 5, 28-38.

38. Smital J., De Sousa L. L., Mohnsen A.: Differences among breeds and manifestation of heterosis in AI boar sperm output. Anim. Reprod. Sci. 2004, 80 121-130.

39. Sonderman J. P., Luebbe J. J.: Semen production and fertility issues related to differences in genetic lines of boars. Theriogenol. 2008, 70, 1380-1383.

40. Sönmez M., Türk G., Yüce A.: The effect of ascorbic acid supplementation on sperm quality, lipid peroxidation and testosterone levels of male Wistar rats. Theriogenol. 2005, 63, 2063-2072.

41. Stryer L., Tymoczko J. L., Berg J. M.: Biochemia. Wydawnictwo Naukowe PWN, Warszawa 2007.

42. Turner R. M. O., Mc Donnell S. M.: Alcaline phosphatase in stallion semen: characterization and clinical applications. Theriogenol. 2003, 60, 1-10.

43. Więckowski $W$.: Studies on the levels of L-ascorbic acid and deficient in vitamin C in pigs. Rozpr. hab. Instytut Weterynarii, Puławy 1980 (in Polish).

44. Wolf J., Smital J.: Quantification of factors affecting semen traits in artificial insemination boars from animal model analyses. J. Anim. Sci. 2009, 87, 1620-1627 .

45. Wysokińska A., Kondracki S.: Assessment of sexual activity levels and their association with ejaculate parameters in two-breed hybrids and purebred Duroc and Pietrain boars. Ann. Anim. Sci. 2014, 14, 559-571.

46. Wysokińska A., Kondracki S., Kowalewski D., Adamiak A., Muczyńska E.: Effect of seasonal factors on the ejaculate properties of crossbred Duroc $\times$ Pietrain and Pietrain $\times$ Duroc boars as well as purebred Duroc and Pietrain boars. Bull. Vet. Inst. Pulawy 2009, 53, 677-685.

47. Yousef M. I., Abdallah G. A., Kamel K. I.: Effect of ascorbic acid and Vitamin E supplementation on semen quality and biochemical parameters of male rabbits. Anim. Reprod. Sci. 2003, 76, 99-111.

Corresponding author: dr hab. Jerzy Lechowski, Akademicka 13, 20-950 Lublin, Poland; e-mail: jerzy.lechowski@onet.eu 